\title{
Przestrzenie Przekładu 4 - międzynarodowa konferencja zorganizowana przez Instytut Filologii Wschodniosłowiańskiej Uniwersytetu Śląskiego w Katowicach, Sosnowiec, 18-19.10.2018 (sprawozdanie)
}

DOI: http://dx.doi.org/10.12775/RP.2019.026

Konferencja „Przestrzenie Przekładu 4” odbyła się w dniach 18-19 października 2018 roku w gmachu Wydziału Filologicznego w Sosnowcu, przy ulicy Grota Roweckiego 5. Obrady są organizowane cyklicznie przez Instytut Filologii Wschodniosłowiańskiej Uniwersytetu Śląskiego w Katowicach. Komitet naukowy tworzą dr hab. Jolanta Lubocha-Kruglik, prof. UŚ, dr hab. Oksana Małysa i dr Gabriela Wilk. Ogromnym atutem konferencji jest imponująca liczba uczestników (także $\mathrm{z}$ wystąpieniami online), prowadzących swoje badania w kraju i zagranicą, specjalizujących się w przekładzie teoretycznym i praktycznym, m.in. rusycystów, slawistów, bałkanistów, anglistów, germanistów i romanistów. Tytuł konferencji w pełni odzwierciedla szeroki wachlarz zainteresowań prelegentów, mnogość prezentowanych metodologii oraz interdyscyplinarne podejście do zagadnień przekładoznawczych. Na corocznych obradach organizatorzy oddają także głos studentom, zwolnionym z opłaty konferencyjnej, którzy mają możliwość przedstawienia własnych zainteresowań badawczych związanych z tematyką przekładu.

W pierwszym dniu konferencji, 18 października 2018 roku, po jej uroczystym otwarciu, organizatorki: dr hab. Jolanta Lubocha-Kruglik, prof. UŚ i dr hab. Oksana Małysa, przewodniczyły obradom plenarnym, w których wystąpiły trzy prelegentki: dr hab. Joanna Dybiec-Gajer, prof. UP (Uniwersytet Pedagogiczny w Krakowie) wygłosiła referat pt. Przekład czy transkreacja - z problematyki tłumaczenia tytułów tekstów naukowych; prof. dr hab. Anna Bednarczyk (Uniwersytet Łódzki) przedstawiła referat pt. Przekład w Internecie - Lila Helena metryka jako tłumaczka Igora Siewierianina oraz doc. dr Simona Koryčánková (Masaryk University) - referat pt. Специфбика перевода поэзии (на примере чешско-русского перевода поэзии О. Бржезины).

Następnie obrady były kontynuowane w czterech sekcjach: przekład artystyczny, przekład specjalistyczny, badania konfrontatywne a badania przekładowe oraz przekład - zagadnienia ogólne. Blokowi tematycznemu poświęconemu przekładowi artystycznemu przewodniczyła prof. dr hab. Anna 
Bednarczyk. Swoje wystąpienia przedstawili następujący prelegenci: prof. dr hab. Henryk Fontański (Uniwersytet Śląski), Petra Murianki przekłady poezji polskiej na język łemkowsk; dr Aleksandra Jackiewicz (Uniwersytet Warszawski), Poezja „wizji” w przekładzie. Jerzy Harasymowicz w tłumaczeniu na język hiszpański; mgr Iryna Hryhorieva (Uniwersytet Łódzki) z referatem: Трудности перевода поэтики Марины Цветаевой; mgr Estera Sobalkowska (Uniwersytet Śląski), Poezja Vasco Popy w przekładach Tadeusza Różewicza oraz mgr Anna Wojciechowska (Uniwersytet Kazimierza Wielkiego w Bydgoszczy), Wplyw strategii i technik tłumaczeniowych na komizm językowy (analiza porównawcza na przykładzie bajki animowanej „Zwierzogród"). Przewodniczącymi obrad w sekcji przekład specjalistyczny byli: prof. dr hab. Sambor Grucza i dr Gabriela Wilk, a prelegentami: dr Anna Bonek (Uniwersytet Warszawski), Kilka uwag $w$ sprawie przedmiotu badań translatoryki legislatywnej; mgr Aleksandra Wojnarowska (Uniwersytet Śląski), Łacińskie nazwy anatomiczne oka i ich słowiańskie ekwiwalenty; mgr Natalia Shlikhutka (Uniwersytet Śląski), Charakterystyka leksyki specjalistycznej na materiale słowackich tekstów; mgr Dawid Bronowski (Uniwersytet Śląski), О специфике перевода терминов из области таможенного права на польский язык (на основании анализа текста Таможенного кодекса Таможенного союза) oraz dr Елена Малеева, mgr Вероника Вайссенхофер (Венский университет прикладных наук), Роль переводчика в сфере медицинского туризма. Sekcji badania konfrontatywne a badania przekładowe przewodniczyły: dr hab. Małgorzata Borek i dr hab. Maria Nienarokowa. Wyniki swoich badań przedstawiło czworo mówców: prof. dr hab. Lubomir Hampl (Akademia Techniczno-Humanistyczna), Aliteracja po raz drugi - porównanie polskiego przekładu z czeskim oryginałem; dr Сергей Сидоренко (Национальный авиационный университет), Языковой сексизм: две перспективы перевода; dr Анастасия Уржа (Московский государственный университет), Реализация семантики персуазивности и неопределенно-личности при переводе фантастических текстов (online) oraz dr Anna Rudyk (Uniwersytet Rzeszowski), Polskie odpowiedniki przekładowe rosyjskiego leksemu „pad”. W sekcji przekład - zagadnienia ogólne, prowadzonej przez dr. hab. Piotra Mameta, prof. Pol. Śl. i dr Ewę Białek, wystąpili: dr hab. Katarzyna Dembska (Uniwersytet Mikołaja Kopernika), O zjawisku eufemizacji w przekładzie (na materiale języka czeskiego); dr Alicja Sztuk (Uniwersytet Warszawski), O konieczności relatywistycznego podejścia do oceny stopnia znormalizowania terminu; mgr Justyna Cichoń (Uniwersytet Śląski), Odpowiedzialność prawna tłumacza; mgr Sławomir Smugowski (Uniwersytet Śląski), O jakości tłumaczenia oraz mgr Marta Dargiewicz (Uniwer- 
sytet Śląski), Rola i zadania tłumacza $w$ procesie negocjacyjnym. Po owocnych obradach dyskusja przeniosła się na przerwę kawową i trwała w kuluarach.

W kolejnej sekcji, poświęconej przekładowi artystycznemu, wystąpieniom przewodniczyli: dr hab. Katarzyna Dembska i prof. dr hab. Lubomir Hampl. Wśród prelegentów znaleźli się: dr hab. Кирилл Александрович Чекалов (Институт мировой литературы им. А.М. Горького РАН), Новый русский Жюль Верн: инериия и инновации в переводах романов франиузского классика (online); dr hab. Małgorzata Borek (Uniwersytet Śląski), Bajki Edwarda Uspienskiego w Polsce; mgr Justyna Fudała (Uniwersytet Wrocławski), O tłumaczeniu literatury brzydkiej i wulgarnej na przykładzie prozy Miodraga Bulatovicia; mgr Dawid Adamczyk (Uniwersytet Śląski), Культурная инаковость в русском переводе книги М. Вилька «Дом над Онего» oraz mgr Szymon Bryzek (Uniwersytet Śląski), O polskich tłumaczeniach utworów Włodzimierza Wysockiego. W sekcji przekład ustny i audiowizualny wystąpiły następujące osoby: dr hab. Piotr Mamet, prof. Pol. Śl. (Politechnika Śląska w Gliwicach), dr Anna Miś (Uniwersytet Śląski), dr Gabriela Wilk (Uniwersytet Śląski), Agent 007 i M we wzajemnych ocenach - polski i rosyjski przekład wybranych fragmentów filmów; dr Iwona Borys (Uniwersytet Warmińsko-Mazurski), Gdy dobrze nie znaczy dobrze: jakość przekładu ustnego w ocenie jego uczestników; dr Agnieszka Palion-Musioł (Akademia Techniczno-Humanistyczna), Audiodeskryptor i jego kompetencje; mgr Dominik Kudła (Uniwersytet Warszawski), „Фapryc”, czyli o rosyjskim przekładzie gier wideo inaczej oraz mgr Maciej Małek (Uniwersytet Śląski), Antroponimy w przekładzie scenicznym. W ostatniej sekcji: Przekład - zagadnienia ogólne. Dydaktyka przekładu, której przewodniczyli dr hab. Joanna Dybiec-Gajer oraz dr Sergiej Sidorenko, było pięć prelegentek: $\mathrm{dr}$ Надежда Голтвяница, dr Елена Хавкина (Запорожский национальный технический университет), Системы контекстуального поиска Linguee, Reverso и ABBYY Lingvo Live в профессиональной деятельности переводчика; dr Agnieszka Andrychowicz-Trojanowska (Uniwersytet Warszawski), $W$ sprawie tzw. ćwiczeń translacyjnych $w$ procesie glottodydaktycznym. Pytania terminologiczne $i$ metodologiczne; dr Ksenia Gałuskina (Uniwersytet Śląski), Nowe technologie $w$ dydaktyce przekładu - założenia i realizacja, czyli czego i jak uczyć; mgr Maria Nikishina (Uniwersytet Warszawski), Nowe technologie w tłumaczeniu: przekład maszynowy i wspomagany komputerowo oraz mgr Светлана Зверева (Минский государственный лингвистический университет), Дидактические возможности САТ-инструментов в повышении качества подготовки переводчиков. 
W drugim dniu konferencji, 19 października 2018 roku, obrady toczyły się w trzech sekcjach: przekład artystyczny, tłumacz i jego dzieło oraz przekład - zagadnienia ogólne. W pierwszej sekcji funkcję przewodniczącej pełniła doc. dr Simona Koryčánková. O przekładzie artystycznym mówiło pięć osób: dr hab. Мария Равильевна Ненарокова (Институт мировой литературы им. А.М. Горького РАН), Латинское средневековое наследие в польском гимнографическом корпусе; dr Anna Pięcińska (Uniwersytet Warszawski), Obraz jako efekt przekładu intersemiotycznego; mgr Wojciech Mischke (Uniwersytet Jagielloński), Pliniuszowy topos $w$ gloryfikacji Pietera Bruegla Starszego i jego recepcja (przekłady) w piśmiennictwie polskim; mgr Łukasz Gęborek (Uniwersytet Śląski), Проявления карнавализации в «Детях Луньљ» Бориса Акунина и их польском переводе oraz mgr Konrad Wójcik (Uniwersytet Śląski), Piosenka "Sarajewo" Jaromíra Nohavicy w przekładach na język polski. W sekcji poświęconej tłumaczowi i jego dziełu, w której prowadzącymi były: dr hab. Joanna Warmuzińska-Rogóż i dr hab. Anna Zych, wystąpiły następujące osoby: dr Patrycja Bobowska-Nastarzewska (Uniwersytet Mikołaja Kopernika), Ocalić formę czy treść ? - o dylematach tłumacza poezji na podstawie własnego przekładu wierszy Leconte de Lisle’a; mgr Katarzyna Christianus-Gileta (Uniwersytet Warmińsko-Mazurski), Poezja Wisławy Szymborskiej w Izraelu w przekładach Rafiego Weicherta; mgr Małgorzata Bachan-Kołodziejska (Uniwersytet Jagielloński), Andrzej Drawicz i Adam Mazur. Dwa portrety językowe jednego tłumacza oraz mgr Paweł Łapiński (Uniwersytet Gdański), Spiritus movens reditus? Wpływ programu Sample Translations @POLAND na pozycję tłumacza literackiego na przykładzie francuskojęzycznego rynku książki. W sekcji: przekład - zagadnienia ogólne, której przewodniczyła dr hab. Oksana Małysa, wysłuchaliśmy referatów czterech prelegentek: dr Галина Гвоздович (Белорусский государственный университет), Лексема МИР в русском языковом пространстве и её эквиваленты в белорусском языке; магистр Надежда Анатольевна Сычёва (Тюменский государственный университет), Соматизм «язык/ jęzуk» в паремиологических единицах русского и польского языков; lic. Татьяна Гаранович (Минский государственный лингвистический университет), Семантико-структурные особенности белорусского синтаксического фразеологизма як было не + инфинитив и способы его перевода на английский язык oraz starszy wykładowca Наталия Островская (Новосибирский государственный университет), Функциональнокоммуникативное поле вариантности в рамках нормативного аспекта перевода (online). Dyskusję kontynuowano na przerwie kawowej, po której obrady wznowiono jednocześnie w trzech sekcjach. 
W sekcji poświęconej przekładowi artystycznemu, prowadzonej przez $\mathrm{dr}$ hab. Jolantę Lubochę-Kruglik, prof. UŚ wystąpiły: dr Małgorzata Ślarzyńska (Uniwersytet Kardynała Stefana Wyszyńskiego), Polska recepcja słowno-obrazowej twórczości Dina Buzzatiego; mgr Zofia Małysa (Uniwersytet Jagielloński), Aspekt kulturowy generowania przypisów w przekładzie literatury pięknej. Francuskie i rosyjskie tłumaczenia „Mapy i terytorium” Michela Houellebecqa; mgr Aneta Wielgosz (Uniwersytet Warszawski), Adaptacja kontekstu kulturowego w polskich przekładach „Bajek przez telefon” Gianniego Rodariego; mgr Lesia Korostatevych (Instytut Slawistyki PAN), Realia kulturowe w przekładach na język ukrainski (na podstawie analizy porównawczej powieści A. Stasiuka); mgr Patrycja Masłowska (Uniwersytet im. Adama Mickiewicza), Tłumaczenie cech stylu Witolda Gombrowicza na język francuski na przykładzie francuskojęzycznej wersji „Pamiętnika z okresu dojrzewania” Georges'a Sedira oraz mgr Aleksander Bogusz (Uniwersytet Śląski), Способы перевода устаревщей лексики и названий реалий (на материале перевода романа M. Краевского «Głowa Minotaura» на русский языıк). W sekcji badania konfrontatywne a badania przekładowe, wielojęzyczność a przekład przewodniczącym był prof. dr hab. Henryk Fontański. Wystąpiły cztery prelegentki: dr hab. Joanna Warmuzińska-Rogóż (Uniwersytet Śląski), Jak przettumaczyć dwujęzyczny oryginat? O możliwym tłumaczeniu na język polski manifestu przekładowego Re-Belle et Infidèle/The Body Bilingual autorstwa Susanne de Lotbinière-Harwood; dr Ewa Białek (Uniwersytet Marii Curie-Skłodowskiej), Rosyjsko-polskie pary przekładowe: studium kilku przypadków; mgr Aleksandra Nocoń (Uniwersytet Śląski), Przekład wielojęzyczności Mauritiusa na język polski na przykładzie współczesnej francuskojęzycznej poezji maurytyjskiej oraz mgr Ганна Филатова (Московский государственный университет), Переосмысление прецедентных феноменов в «мифологической трилогии» Р. Желязны и её русских переводах (online). W sekcji studenci o przekładzie zabrało głos sześcioro uczestników, w tym: lic. Paweł Kruglik (Uniwersytet Śląski), Проявления категории чужого в романе «Ночар" Магдалены Козак и его русском переводе; lic. Karina Jakuć (Uniwersytet Śląski), Переводческие трансбормации в переводе повести Иоанны Хмелевской «Пафнутий» на русский язык; lic. Bartłomiej Jochymczyk (Uniwersytet Śląski), Rosyjskie wersje polskich piosenek; Aleksandra Gnyp (Uniwerystet Śląski), Переводческие техники в польской версии фильма «9 рота»; lic. Judyta Mężyk (Uniwersytet Śląski), Międzyjęzykowy transfer $w$ angielsko-polskich napisach do filmu tłumaczonych maszynowo oraz lic. Дарья Денисова (БФУ им. Канта), Особенности перевода компьютерных игр (online). 
Konferencja „Przestrzenie Przekładu 4” była wyjątkowo miłą okazją do spotkania specjalistów oraz pasjonatów przekładoznawstwa. Uczestnicy konferencji aktywnie brali udział w obradach, czyniąc je niezmiernie ciekawymi, rozwijającymi i twórczymi. Po raz kolejny organizatorzy, w tym szczególnie dr hab. Jolanta Lubocha-Kruglik, prof. UŚ i dr hab. Oksana Małysa, stworzyli niezwykłą atmosferę życzliwości i otwartego dialogu, co znalazło odzwierciedlenie w pasjonującej i żywej dyskusji. Przyjazna postawa wobec wystąpień studentów, którzy mieli szansę zweryfikowania efektów swoich badań, oraz konstruktywna krytyka prelegentów pozwala mieć nadzieję na dalszy owocny rozwój dziedziny naukowej, jaką jest przekładoznawstwo.

Patrycja Bobowska-Nastarzewska Uniwersytet Mikołaja Kopernika w Toruniu bobowska@umk.pl 